\title{
VERBA LEMPAR BAHASA SASAK: KAJIAN METABAHASA SEMANTIK ALAMI
}

\author{
Irma Setiawan \\ Program Studi Pendidikan Bahasa dan Sastra Indonesia \\ FKIP Universitas Muhammadiyah Mataram \\ Pos-el: Irmasetiawan9@gmail.com
}

\begin{abstract}
Abstrak
Verba lempar dalam bahasa Sasak (BSs) memiliki beberapa variasi leksikon yang menunjukkan perbedaan konteks makna yang diacu. Kegiatan melempar memiliki penyebutan berbeda, bergantung pada cara dan benda yang digunakan dalam melempar, akibat yang dapat ditimbulkan pada sasaran juga berbeda-beda, dan intensitas tindakan dalam setiap aksi lempar berkorelasi dengan dampak tindakan. Telaah verba ini dikaji dalam perspektif Metabahasa Semantik Alami (MSA) sebagai salah satu bentuk pengkajian semantik modern yang digagas Wierzbicka (1996) yang bertujuan untuk memerikan makna leksikal, gramatikal, dan ilokusi dalam suatu bahasa. Penelahaan ini tentu didasari atas 65 makna asali yang telah diformulasikan dalam MSA. Proses yang dipergunakan dengan teknik eksplikasi (parafrase) dalam memerikan verba lempar. Hasil yang diperoleh bahwa verba lempar memiliki pengkategorian berdasarkan intensitas (time), media (attributes), dan dampak tindakan yang ditimbulkan.
\end{abstract}

Kata Kunci: verba lempar, variasi makna, MSA.

\section{PENDAHULUAN}

Bahasa merupakan representasi pemikiran manusia yang paling baik. Dalam bahasa segala informasi dapat tersampaikan dan terealisasikan antara penutur dan petutur. Suatu bahasa sebagai wujud reprsentasi makna yang dibentuk berdasarkan kesepakatan masyarakat. Weirzbicka (1996:3) menyatakan bahasa merupakan instrumen untuk kesepakan makna, dalam hal ini kesepakatan antara partisipan dalam bahasa. lebih lanjut, antara bahasa dan makna, Reicoeur (2005:14) bahwa suatu kata itu sendiri tidaklah bersifat benar atau salah, meskipun sekumpulan kata-kata bisa bermakna sebagai sesuatu ataupun tak bermakna sebagai sesuatu. Artinya, suatu kata akan sangat bermakna dalam komunitas tertentu, tetapi untuk masyarakat lain kata tersebut belum tentu dianggap bernilai. Secara alami, bahasa memiliki makna yang terbentuk dari interaksi antarpartisipan, sehinga dalam realitas suatu kata dapat memiliki variasi, tetapi secara general mengacu pada satu makna inti. Misalnya pada verba 'lempar'.

Verba 'lempar' dalam Bahasa Sasak (BSs) adalah kelas kata kerja yang ditunjukkan dengan aktivitas atau tindakan melakukan sesuatu hal untuk tujuan tertentu. Dalam 'lempar' terdapat pelaku 
tindakan ' $\mathrm{X}$ ' dan sasaran tindakan ' $\mathrm{Y}$ '. Kedua aspek ini berinteraksi sehingga membentuk variasi dalam tindakan 'lempar'. Variasi dalam tindakan 'lempar' mencakup tiga hal, yakni intensitas atau waktu, media atau atribut yang digunakan, dan efek atau dampak tindakan yang dilakukan pelaku ' $\mathrm{X}$ '. Ketiga kriteria ini dapat memperlihatkan fitur semantik pada setiap variasi leksikon verba 'lempar'. Aspek intensitas memuat tingkatan waktu dalam bertindak, aspek media atau atributif memuat komponen benda atau bahan yang dijadikan media dalam aksi 'lempar', dan efek atau hasil tindakan memuat akibat yang dapat ditimbulkan dari media dan intensitas tindakan. Ketiga aspek ini juga dapat dikatakan sebagai konteks tindakan (Wierzbicka, 2003).

Realisasi tindakan 'lempar' memiliki perbedaan, tergantung pada konteks 'lempar' yang diujarkan ' $\mathrm{X}$ ' terhadap ' $\mathrm{Y}$ '. Pada tataran tertentu, verba 'lempar' dapat dimaknai tindakan yang dilakukan dengan intensitas sekali, tetapi dalam leksikon 'lempar' yang lain pada BSs dapat bermakna tindakan yang dilakukan berkalikali. Selanjutnya, atribut tindakan dapat berupa media yang digunakan untuk melempar, seperti benda dengan beragam ukuran beda leksikon dan jumlah benda untuk melempar dapat memengaruhi penyebutan leksikon (Wierzbicka, 2003).
Keberadaan aspek-aspek asali ini secara langsung memperlihatkan fitur semantik yang terkandung dalam verba 'lempar'. Fitur semantik ini juga dapat memetakan makna suatu verba dalam beragam konteks penggunaan. Misalnya, verba 'lempar' dalam klauasa tuturan atau dalam suatu ujaran. Dalam pada itu, penggunaan pendekatan MSA sebagai paradigma modern dalam pengkajian semantik. Teori ini dianggap cukup memadai dalam menelaah makna verba 'lempar' BSs. Analisis yang dilakukan dengan MSA dapat mengewajantahkan suatu asumsi yang menjadi dalil makna, yakni satu bentuk untuk satu makna dan satu makna untuk satu bentuk. Dalam konsep yang lebih luas, satu makna diwakilkan atas satu bentuk leksikon dan satu leksikon untuk satu makna, meski dalam penyebaran leksikon berasal dari satu akar leksikon.

\section{LANDASAN TEORI}

Bahasa memiliki arti dan makna. Keduanya merupakan dua hal berbeda. Arti dalam bahasa tercipta secara leksikal, sedangkan makna termuat karena persepsi penyimak secara gramatikal. Konsep makna setiap orang dalam bahasa berbedabeda. Tetapi, Weirzbicka (1996:3); Allan (2016) menyatakan bahasa merupakan instrumen untuk kesepakan makna. Artinya, di dalam bahasa terdapat 
kesepakatan makna yang digunakan untuk melabelkan sesuatu bahasa untuk maksud tertentu. Terkait dengan makna, Weirzbicka (1996) mengembangkan suatu teori pengkajian makna dengan terfokus pada aspek leksikal, gramatikal, dan ilokusi yang didikenal dengan teori Natural Semantic Metalanguage (NSM) yang kemudian adaptasi dalam bahasa Indonesia menjadi Metabahasa Semantik Alami (MSA). Perkembangan teori ini cukup pesat dikarenakan dalam kajian semantik teori ini cukup modern.

Penggunaan pendekatan ini diyakini dapat secara akurat dan menukik dalam menganalisis makna alamiah yang terkandung dalam suatu bahasa (leksikon). Pengkajian terhadap verba 'lempar' BSs sebagai bentuk penerapan teori MSA dalam pengkajian unsur alamiah bahasa. Konsep kealamiahan suatu bahasa diyakini dapat direpresentasikan dengan asumsi satu makna satu bentuk atau sebaliknya satu bentuk untuk satu makna. Pandangan ini dalam MSA ini lah yang kemudian dipergunakan untuk mencermati kealamiahan suatu tata bahasa, yakni kata (leksikon). Proses penelaahan kealamiahan bahasa dalam MSA dipergunakan teknik parafrase atau eksplikasi yang bertujuan untuk melihat pola kata dan makna dalam konsep satu makna satu bentuk atau satu bentuk satu makna. Hal ini telah ditegaskan Wierzbicka (1996:10); Sudipa (2004) eksplikasi dengan sendirinya dapat dipahami oleh semua penutur asli bahasa yang bersangkutan. Pernyataan ini memiliki korelasi dengan prinsip semiotik yang dinyatakan dalam kutipan di bawah ini.

A sign cannot be reduced to or analyze into ani combination of things which are not themselves signs; consequently, it is imposible to reduce meanings to any combination of things which are not themselves menaing (Wierzbicka, 1996:10)

Prinsip yang dipaparkan di atas, dinyatakan bahwa suatu makna akan menjadi terpisah-pisah (diskret) dan tuntas, dalam arti makna kompleks apapun itu dapat dijelaskan tanpa perlu berputar-putar dan tanpa residu dalam kombinasi makna terpisah yang lain (Goddard, 1996:24);Sutjiati-Beratha, 997:110;Sudipa, 2004). Artinya, dengan konsep satu makna untuk satu bentuk atau satu bentuk untuk satu makna dapat dipergunakan untuk menyatakan makna secara diskret dan tuntas tanpa harus mengulas secara berulang-ulang yang dapat berakibat penjelasan menjadi kabur dan tidak tuntas.

Terdapat beberapa konsep teoretis dalam teori MSA untuk pengkajian verba 'lempar' BSs (Wierzbicka, 1996; Sudipa, 2004) di antaranya, a) makna asali, (semantics primitives), b) polisemi takkomposisi, b) aloleksi, d) sintaksis 
MSA, dll. Adapun penjelasannya, sebagai berikut.

a) Makna asali (semantics primitives) ialah perangkat makna yang tidak berubah karena diwariskan manusia sejak lahir (Goddard, 1996:2). Piranti makna asali ini merupakan salah satu asumsi utama dalam teori MSA. Makna ini dianggap sebagai pengewanjatahan konsep berpikir manusia terhadap suatu entitas kebahasaan secara alami, artinya makna terbentuk secara turun menurun dalam pikiran manusia pada setiap generasinya. Pengungkapan makna asali dalam teori MSA hanya dapat dilakukan dengan teknik parafrase atau eplikasi (Wierzbicka, 1996:31). Lebih lanjut, dalam pemerian makna asali (semantics primitives), Wierzbicka (1996:35); (2003:8) menawarkan 65 makna asali, dalam kategori (old primitives dan new primitives) yakni.

$\begin{array}{lll}\text { Substantives } & : & \text { I, YOU, SOMEONE, } \\ & & \text { SOMETHING,PEOPLE, BODY } \\ \text { Relation Substantives } & : & \text { KIND OF, PART OF } \\ \text { Determiners } & : & \text { THIS, THE SAME, OTHER } \\ \text { Quantifiers } & : & \text { ONE, TWO, ALL, } \\ & : & \text { MANY/MUCH, SOME } \\ \text { Atributtes } & : & \text { VERY } \\ \text { Intensifiers } & : & \text { WANT, FEEL, THINK, KNOW, } \\ \text { Mental Predicates } & & \text { SEE, HEAR } \\ \text { Speech } & : & \text { SAY, WORDS, TRUE } \\ \text { Action events, movements } & : & \text { DO, HAPPEN, MOVE } \\ \text { Existence and Possessive } & : & \text { THERE IS, HAVE } \\ \text { Life and Death } & : & \text { LIVE, DIE } \\ \text { Logical Concept } & : & \text { NOT, MAYBE, CAN, } \\ \text { Time } & : & \text { BECAUSE, IF } \\ & & \text { WHEN, NOW, AFTER, } \\ \text { MOMENT } & & \text { BEFORE, A LONG TIME } \\ \text { Space } & : & \text { WHERE, HERE, ABOVE, } \\ & & \text { BELOW, NEAR, FAR, INSIDE, } \\ \text { CONTACT } & & \text { SIDE, TOUCHING } \\ \text { Augmentor } & : & \text { MORE } \\ \text { Similiarity } & : & \text { LIKE (HOW, AS) }\end{array}$


b) Polisemi takkomposisi ialah bentuk leksikon tunggal yang dapat mengekspresikan dua makna asali yang berbeda (Wierzbicka, 1996;Sudipa, 2004). Kedua makna asali ini dikorelasikan melalui suatu pemaknaan yang muncul karena adanya hubungan polisemi takkompoisisi antara satu eksponen dengan eksponen lain. Dalam polisemi takkomposisi ini dapat memicu kemunculan konsep makna yang beragam terhadap satu entitas. Misalnya: dalam verba 'lempar' pelentong $\rightarrow$ rambu kedua kata ini memiliki makna umum 'lempar', tetapi dalam konteks kealamiahan makna verba terjadi polisemi takkomposisi antara TINDAKAN dan AKIBAT TINDAKAN, sehinggga pengalaman makna asali yang diperoleh " $\mathrm{X}$ melakukan sesuatu, dan karena itu $Y$ benjol" atau "X melakukan sesuatu, dan karena itu Y kelilipan”.

Kedua konsep epiklasi, yakni makna asali dan polisemi takkomposisi ini dijadikan piranti pengarah telaah yang dikembangkan berdasarkan 61 makna asali di atas, untuk mencermati verba 'lempar' yang berwujud TINDAKAN $\rightarrow$ AKIBAT TINDAKAN. Berikutnya, Wierzbicka (1996:35);(2003); $\quad$ Sutjiati-Beratha (2000:248); Sudipa (2004) dalam parafrase harus mengikuti beberapa kaidah, sebagai berikut.

a) Parafrase harus menggunakan kombinasi sejumlah makna asali yang telah diusulkan Wierzbicka. Kombinasi sejumlah makna asali diperlukan terkait dengan klaim dari teori MSA, yaitu suatu bentuk tidak dapat diuraikan dengan memakai satu makna asali.

b) Parafrase dapat pula dilakukan dengan memakai unsur yang merupakan kekhasan suatu bahasa. Hal ini dapat dilakukan dengan mengambungkan unsur-unsur yang merupakan keunikan bahasa itu sendiri untuk menguraikan makna.

c) Kalimat parafrase selalu menggunakan bahasa sederhana.

d) Kalimat parafrase kadang-kadang memerlukan indentasi dan spasi khusus.

\section{METODE PENELITIAN}

Penelitian ini menggunakan pendekatan deskriptif kualitatif yang berupaya mengelaborasi fenomena kebahasaan yang terjadi dalam debat Capres. Lokasi penelitian dilakukan pada Etnis Sasak di Pulau Lombok, khususnya di daerah Selong Lombok Timur. Jenis data yang diperoleh beruapa data tekstual yang diperoleh melalui catatan observasi peneliti dilapangan melalui metode simak dan cakap yang kemudian dicatat secara cermat untuk mendapatkan leksikon 
'lempar'. Data yang diperoleh dikategorikan dalam sub-kategori makna asali. Data terkumpul yang berjumlah 13 kosakata. Penentuan jumlah data didasari atas pandangan Samarin (1988) bahwa sampel cukup seseorang atau satu data tetapi representatif. Namun, dibantah Mahsun (2007:29) terlalu riskan jika data sampel hanya seseorang atau satu data saja, karena data yang diperoleh tidak bisa dikoresikan silang demi keabsahannya, sehingga peneliti dalam telaah ini berusaha menggunakan datalebih dari satu dengan batas maksimal tindak ditentukan, tetapi peneliti menetapkan 13 data leksikon 'lempar'.

Instrumen yang dipergunakan dalam penelitian berupa buku catatan kecil untuk pencatatan dan pengkategorian data, serta lembar verifikasi untuk keabsahan data. Metode pengumpulan data dilakukan dengan metode catatan dokumentasi dan observasi lapangan yang berisi berupa dokumen. Teknik pengumpulan data yang dipergunakan, yakni; teknik baca guna pencermatan dan pemolaan data dan teknik catat guna mendata dan melihat variasi makna asali pada leksikon 'lempar'. Metode penganalisisan yang dipergunakann dalam penelitian ini, yakni metode kualitatif. Metode penyajian yang digunakan dalam penelitian ini berupa metode formal dan informal (Sudariyanto, 1993:144; Mahsun, 2007:123).

\section{PEMBAHASAN}

Verba 'lempar' yang diperoleh dalam bahasa Sasak berjumlah 13 variasi dengan makna mewakili satu bentuk atau satu bentuk mewakili satu makna. Keseluruhan variasi verba 'lempar' ini tetap secara umum bermakna 'lempar', hanya saja secara spesifik mengandung makna yang berbeda-beda, baik ditinjau pada aspek hubungan subjek-objek, properti, cara, dan bentuk tindakan. Katakata yang yang ditemukan, seperti: amet, pelentong, rambu, sawut, telep, timpoh, timpak, timpek, kaeh, sawur, sangkurang, dan koeh. Parafrase seluruh data temuan pada verba 'lempar' ke dalam konstruksi kanonis yang didesain berdasarkan lanngkah analisis yang ditawarkan Wirezbicka (1996;2003). Adapun deskripsi telaah MSA pada verba 'lempar' yang dikelompokkan berdasarkan cara, properti, dan tujuan tindakan atau aksi, sebagai berikut.

\section{Amet, pelentong, ampes}

Leksikon amet memiliki fitur semantik yang mengabstraksikan seseorang yang melakukan tindakan melempar terhadap sasaran (objek) yang berupa benda hidup. Properti yang digunakan melempar berupa benda mati, 
seperti batu ukuran kepalan tangan biasa. Sasaran aksi ditujukan untuk mencederai apabila sasaran benda hidup dan menjatuhkan apabila sasaran benda mati. Proses melempar yang dilakukan menggunakan satu tangan (kiri atau kanan, tetapi biasanya tangan kanan) yang diayunkan dari atas pundak membentuk sudut $90^{\circ}$ setelah pelemparan. Tenaga tindakan biasanya kuat dan dilakukan secara sengaja. Selanjutnya, objek sebagai sasaran (benda hidup) tidak menyadari dirinya di lempar. Dalam abstraksi eksplikasi kata amet dapat dideskripsikan berikut ini.

Pada waktu itu, X melakukan sesuatu pada $\mathrm{Y}$

Karena ini, pada waktu bersamaan sesuatu terjadi pada Y (cedera)

$\mathrm{X}$ melakukan sesuatu dengan cara tertentu (tangan mengayun tangan dari atas ke bawah membentuk sudut $90^{\circ}$ )

$\mathrm{X}$ melakukan sesuatu pada $\mathrm{Y}$ karena menginginkan $\mathrm{Z}$

$X$ melakukan dengan benda tertentu (batu seukuran kepalan tangan)

$\mathrm{X}$ melakukan tindakan dengan satu tangan

Leksikon pelentong memiliki fitur semantik berupa tindakan yang dilakukan $X$ secara sengaja mencederai $X$. Semua tindakan $\mathrm{X}$ mempergunakan benda berupa balokan kayu/bambu dan sejenisnya. Tindakan yang dilakukan dengan mengayunkan tangan dari atas sejajar bahu yang membentuk sudut $90^{\circ}$ setelah pelemparan. Sasaran tindakan $\mathrm{X}$ lebih diarahkan pada mahkluk hidup (manusia dan hewan), sehingga berakibat dapat melukai Y. Deskripsi eksplikasi berikut ini.

Pada waktu itu, $\mathrm{X}$ melakukan sesuatu pada $\mathrm{Y}$

Karena ini, pada waktu bersamaan sesuatu terjadi pada Y (terjatuh)

$\mathrm{X}$ melakukan sesuatu dengan cara tertentu (tangan mengayun tangan dari atas ke bawah membentuk sudut $90^{\circ}$ )

$\mathrm{X}$ melakukan sesuatu pada $\mathrm{Y}$ karena menginginkan $\mathrm{Z}$

$X$ melakukan dengan benda tertentu (batang/balok/ranting kayu dan sejenisnya)

$\mathrm{X}$ melakukan tindakan dengan satu tangan

Leksikon ampes merupakan tindakan yang dilakukan $\mathrm{X}$ terhadap $\mathrm{Y}$ sehingga berakibat terjatuh. Tindakan $\mathrm{X}$ haanya dilakukan untuk benda mati dan bukan ditujukan pada benda hidup. Tindakan X dilakukan dengan satu tangan mengayunkan benda berupa batu dan balokan kayu atau sejenisnya pada $\mathrm{Y}$. Ukuran benda atau alat tindakan seukuran sedang untuk balokan atau batang kayu dan sejenisnya serta ukuran kepalan tangan untuk batu. Berbeda dengan tindakan pada leksikon amet dan pelentong yang ditujukan hanya pada benda hidup saja atau benda mati. Deskripsi eksplikasi leksikon, sebagai berikut.

Pada waktu itu, X melakukan sesuatu pada $\mathrm{Y}$ 
Karena ini, pada waktu bersamaan sesuatu terjadi pada $\mathrm{Y}$ (cedera atau terjatuh)

$\mathrm{X}$ melakukan sesuatu dengan cara tertentu (tangan mengayun tangan dari atas ke bawah membentuk sudut $90^{\circ}$ )

$\mathrm{X}$ melakukan sesuatu pada $\mathrm{Y}$ karena menginginkan $\mathrm{Z}$

$X$ melakukan dengan benda tertentu (batu seukuran kepalan tangan dan batang/balok/ranting kayu dan sejenisnya)

$\mathrm{X}$ melakukan tindakan dengan satu tangan

\section{Timpoh, timpak, timpek, telep}

Leksikon timpoh memiliki fitur semantik berupa tindakan $\mathrm{X}$ dilakukan terhadap entitas benda hidup (manusia dan hewan). Tindakan $\mathrm{X}$ dilakukan pada $\mathrm{Y}$ dengan tujuan dilempar ke kali, kolam, atau sungai. Kegiantan ini dilakukan secara sengaja. Cara yang dilakukan dengan mengayunkan kedua tangan dari bawah ke atas. Artinya, arah terbalik bila dibandingkan dengan tindakan amet, pelentong, ampes. Kegiatan ini dilakukan hanya sesekali, tidak berulang-ulang. Gerakan tindakan hanya ayunan kedua tangan (tidak menggunakan satu tangan). Tekanan tenaga X terhadap Y cukup besar, karena $\mathrm{X}$ harus mengangkat $\mathrm{Y}$ kemudian melemparnya ke sisi terbawah pada kali, kolam, atau sungai. Deskripsi eksplikasinya, berikut ini.

Pada waktu itu, X melakukan sesuatu pada $\mathrm{Y}$
Karena ini, pada waktu bersamaan sesuatu terjadi pada Y (cedera)

$\mathrm{X}$ melakukan sesuatu dengan cara tertentu (tangan mengayun tangan dari bawah ke atas membentuk sudut $90^{\circ}$ )

$\mathrm{X}$ melakukan sesuatu pada $\mathrm{Y}$ karena menginginkan $\mathrm{Z}$

$X$ melakukan sesuatu dengan mengakat $\mathrm{Y}$ untuk dilempar ke bidang tertentu

$\mathrm{X}$ melakukan tindakan dengan dua tangan secara bersamaan

Leksikon timpak memiliki fitur makna yang menunjukkan tindakan $\mathrm{X}$ dilakukan pada Y secara sengaja. Tindakan yang dilakukan X cukup keras/kuat. Proses tindakan dilakukan dengan ayunan kedua tangan secara bersamaan. $\mathrm{Y}$ sebagai penerima tindakan dapat berupa benda mati dan benda hidup. Aksi yang dilakukan biasanya dilempar pada bidang seperti lantai dan sejenisnya. Berikutnya, benda yang digunakan bahan melempar dapat berupa benda hidup atau bahkan Y dijadikan objek yang dilempar. Adapun deskripsi eksplikasi makna asalinya sebagai berikut.

Pada waktu itu, $\mathrm{X}$ melakukan sesuatu pada $\mathrm{Y}$

Karena ini, pada waktu bersamaan sesuatu terjadi pada Y (cedera atau terjatuh)

$\mathrm{X}$ melakukan sesuatu dengan cara tertentu (tangan mengayun tangan dari atas ke bawah membentuk sudut $90^{\circ}$ )

$\mathrm{X}$ melakukan sesuatu pada $\mathrm{Y}$ karena menginginkan $\mathrm{Z}$

$X$ melakukan dengan benda tertentu (batu seukuran kepalan 


\author{
tangan dan mengangkat benda \\ hidup untuk dilempar) \\ $\mathrm{X}$ melakukan tindakan dengan \\ dua tangan secara bersamaan
}

Leksikon timpek merupakan tindakan yang dilakukan entitas $\mathrm{X}$ terhadap $\mathrm{Y}$ yang berakibat $\mathrm{Y}$ mengalami sesuatu berupa cedera. Aksi yang dilakukan $\mathrm{X}$ dapat menggunakan batu besar (abstraksi dua kali lebih besar dari telapak tangan). Sasaran tindakan (Y) hanya berupa mahkluk hidup (manusia dan hewan). Proses tindakan hanya dilakukan kedua lengan tangan secara simultan. Gerakan tindakan dari bawah ke atas. Lebih jelasnya, dapat dicermati eksplikasi leksikon timpek di bawah ini.

Pada waktu itu, X melakukan sesuatu pada $\mathrm{Y}$

Karena ini, pada waktu bersamaan sesuatu terjadi pada Y (cedera)

$\mathrm{X}$ melakukan sesuatu dengan cara tertentu (tangan mengayun tangan dari bawah ke atas membentuk sudut $90^{\circ}$ )

$\mathrm{X}$ melakukan sesuatu pada $\mathrm{Y}$ karena menginginkan $\mathrm{Z}$

$X$ melakukan dengan benda tertentu (batu seukuran dua kali kepalan tangan dan batang/balok/ranting kayu dan sejenisnya)

$\mathrm{X}$ melakukan tindakan dengan satu tangan

Leksikon telep memiliki fitur semantik berupa tindakan $\mathrm{X}$ dilakukan dengan melempar Y ke dalam air. Wadah tempat melempar dapat berupa kolam, sungai, atau segala sesuatu yang terisi air.
Tindakan X dilakukan secara perlahanlahan. Tekanan tindakan $\mathrm{X}$ terhadap $\mathrm{Y}$ dilakukan lemah. Akibat tindakan yang dialami Y berupa tenggelam atau terjatuh. Gerakan tindakan dilakukan dengan satu atau kedua tangan (pilihan) dengan posisi lengan tangan di atas ke bawah. Seperti pada eksplikasi di bawah ini.

Pada waktu itu, $\mathrm{X}$ melakukan sesuatu pada $\mathrm{Y}$

Karena ini, pada waktu bersamaan sesuatu terjadi pada Y (cedera atau terjatuh)

$\mathrm{X}$ melakukan sesuatu dengan cara tertentu (tangan mengayun tangan dari atas ke bawah membentuk sudut $90^{\circ}$ )

$\mathrm{X}$ melakukan sesuatu pada $\mathrm{Y}$ karena menginginkan $\mathrm{Z}$

$\mathrm{X}$ melakukan dengan benda tertentu (batu seukuran kepalan tangan, batang/balok/ranting kayu dan sejenisnya, dan makhluk hidup (manusia dan hewan)

$\mathrm{X}$ melakukan tindakan dengan satu tangan

\section{Sawur, sangkurang, kaeh, koeh}

Leksikon sawur berkaitan dengan tindakan 'lempar' yang bertujuan tidak mengenai suatu entitas, melainkan memberikan benda dengan cara melempar. Entitas tidak mengalami cidera dan rasa sakit, melainkan entitas diberikan sesuatu hal dengan tujuan tertentu. Benda yang dapat digunakan untuk tindakan ini berupa benda berukuran kecil dan berjumlah banyak yang disengaja dihamburkan di lantai agar entitas yang dituju mengambil 
atau memungutnya. Dampak yang dirasakan $\mathrm{Y}$ terhadap tindakan $\mathrm{X}$ hanya berupa rasa lelah dalam memungut. Tindakan ini dilakukan dengan cara mengayunkan tangan dari kiri ke kanan atau kanan ke kiri (membentuk bidang horizontal) sehingga hasil tindakan benda tidak terlempar terlalu jauh (jarak dekat). Adapun eksplikasinya sebagai berikut.

Pada waktu itu, X melakukan sesuatu pada $\mathrm{Y}$

Karena ini, pada waktu bersamaan sesuatu terjadi pada Y (lelah)

$\mathrm{X}$ melakukan sesuatu dengan cara tertentu (tangan mengayun tangan dari kiri ke kanan atau kanan ke kiri/horizontal)

$\mathrm{X}$ melakukan sesuatu pada $\mathrm{Y}$ karena menginginkan $\mathrm{Z}$

$X$ melakukan dengan benda tertentu (benda mati, berupa batu berukuran kecil/biji beras, dll)

$\mathrm{X}$ melakukan tindakan dengan satu tangan

Leksikon sangkurang berupa variasi verba 'lempar' yang memiliki fitur semantk, yakni tindakan yang dilakukan X pada Y, sehingga mengakibatkan $\mathrm{Y}$ dikenai pekerjaan untuk melakukan tindakan yang yang diharapkan X. Benda yang digunakan dalam bertindak tidaklah terbatas pada ukuran, artinya dapat berupa benda berukuran kecil, sedang, dan besar (seukuran dua kali kepalan tangan). Bentuk benda yang digunakan dalam bertindak dapat berupa batu, kayu, biji beras, dll. Cakupan tindakan lebih luas dibandingkan leksikon sawur. Lebih jelasnya dapat dieksplikasi, sebagai berikut.

Pada waktu itu, $\mathrm{X}$ melakukan sesuatu pada $\mathrm{Y}$

Karena ini, pada waktu bersamaan sesuatu terjadi pada Y (dikenai pekerjaan)

$X$ melakukan sesuatu dengan cara tertentu (tangan mengayun tangan dari kiri ke kanan atau kanan ke kiri)

$\mathrm{X}$ melakukan sesuatu pada $\mathrm{Y}$ karena menginginkan $\mathrm{Z}$

$X$ melakukan dengan benda tertentu (benda mati yang berukuran kecil, sedang, dan besar, seperti batu, kerikil, biji beras, kayu, dll.)

$\mathrm{X}$ melakukan tindakan dengan dua tangan

Leksikon kaeh merupakan tindakan yang berupa aksi 'lempar' dengan cara yang tidak biasa, yakni dengan menggunakan kaki atau salah satu kaki. Tujuan tindakan biasanya untuk memberikan suatu benda terhadap entitas yang dituju. $\mathrm{X}$ melakukan tindakan tidak berakibat $\mathrm{Y}$ mengalami kesakitan atau cedera, melainkan memberikan suatu benda kepada $\mathrm{Y}$ sehingga secara tidak langsung Y dikenai pekerjaan. Benda yang digunakan dalam bertindak berkuran sedang. Arah gerakan kaki dari depan ke belakang. Jangkauan lemparan tidak terlalu jauh karena bertujuan pada entitas disekitar (dekat). Deskripsinya melalui eksplikasi berikut ini.

Pada waktu itu, $\mathrm{X}$ melakukan sesuatu pada $\mathrm{Y}$ 
Karena ini, pada waktu bersamaan sesuatu terjadi pada Y (dikenai pekerjaan)

$\mathrm{X}$ melakukan sesuatu dengan cara tertentu (kaki diayun dari arah depan ke belakang)

$\mathrm{X}$ melakukan sesuatu pada $\mathrm{Y}$ karena menginginkan $\mathrm{Z}$

$X$ melakukan dengan benda tertentu (segala benda mati yang berukuran sedang)

$\mathrm{X}$ melakukan tindakan dengan satu kaki.

Leksikon koeh berupa tindakan yang memiliki fitur makna yang sidikit berbeda dengan leksikon kaeh. Pada leksikon koeh sasaran entitas berada di samping, sedangkan pada leksikon kaeh entitas berada di depan atau belakang. Tindakan 'lempar' yang dilakukan dengan menggunakan kaki dan tangan (salah satu dapat dipergunakan). Tindakan X pada Y, sehingga $\mathrm{Y}$ mengalami pekerjaan atau dikenai pekerjaan X. Hal yang dirasakan entitas Y pada aksi X, bahwa Y terbantu dari tindakan lempar, karena $\mathrm{X}$ memberikan suatu benda tertentu pada Y. Secara rinci tindakan ini dapat dieksplikasikan, berikut ini.

Pada waktu itu, X melakukan sesuatu pada $\mathrm{Y}$

Karena ini, pada waktu bersamaan sesuatu terjadi pada Y (cedera atau terjatuh)

$\mathrm{X}$ melakukan sesuatu dengan cara tertentu (tangan mengayun tangan dari atas ke bawah membentuk sudut $90^{\circ}$ )

$\mathrm{X}$ melakukan sesuatu pada $\mathrm{Y}$ karena menginginkan $\mathrm{Z}$

$X$ melakukan dengan benda tertentu (batu seukuran kepalan tangan, batang/balok/ranting kayu dan sejenisnya, dan makhluk hidup (manusia dan hewan)

$\mathrm{X}$ melakukan tindakan dengan satu tangan

\section{Rambu}

Leksikon rambu sebagai bagian dari tindakan 'lempar' yang dilakukan dengan cara berbeda dibandingkan leksikon sebelumnya. Leksikon ini dilakukan dengan melakukan tindakan melempar pada suatu entitas dengan tujuan mencederai suatu entitas. Tindakan ini dilakukan dalam jara dekat dengan posisi $\mathrm{X}$ berhadapan dengan Y. Bagian entitas yang dijadikan tujuan aksi, hanya pada bagian pengliahatan entitas. Artinya, tindakan ini hanya melempar bagian mata atau penglihatan pada suatu entitas. Tindakan yang dilakukan $\mathrm{X}$ dapat berakibat Y mengalami kesakitan pada bagian penglihatan (kelilipan). Adapun deksripsi eksplikasinya, berikut ini.

Pada waktu itu, $\mathrm{X}$ melakukan sesuatu pada $\mathrm{Y}$

Karena ini, pada waktu bersamaan sesuatu terjadi pada Y (cedera atau kelilipan)

$\mathrm{X}$ melakukan sesuatu dengan cara tertentu (tangan diayunkan secara vertikal dari atas ke bawah membentuk sudut $90^{\circ}$ )

$\mathrm{X}$ melakukan sesuatu pada $\mathrm{Y}$ karena menginginkan $\mathrm{Z}$

$\mathrm{X}$ melakukan dengan benda tertentu (benda kecil, seperti pasir, tanah, tepung, dll.) 

satu tangan

$\mathrm{X}$ melakukan tindakan dengan

Sawut

Bentuk leksiko 'lempar' yang terakhir dengan variasi sawut. Leksikon ini memiliki fitur makna yang berbeda dengan beberapa variasi leksikon 'lempar' sebelumnya. Tindakan yang dilakukan $\mathrm{X}$ berada pada posisi yang tidak sejajar dengan $\mathrm{Y}$, yakni $\mathrm{X}$ berada pada bagian yang lebih tinggi dari Y. Arah tindakan hanya ke bawah karena posisi $\mathrm{X}$ lebih tinggi dari $\mathrm{Y}$ yang menjadi entitas sasaran aksi. Benda yang digunakan dalam tindakan dapat berupa benda hidup atau benda mati. Akibat yang ditimbulkan atas aksi X pada Y berupa cidera atau luka. Benda yang dilempar berukuran kecil, sedang, dan besar. Aksi ini dilakukan dengan menggunakan kedua lengan tangan (khusus benda yang berukuran besar) dan menggunakan satu tangan pada benda yang berukuran kecil dan sedang. Secara rinci dapat diabstraksikan melalui eksplikasi berikut ini.

Pada waktu itu, X melakukan sesuatu pada $\mathrm{Y}$

Karena ini, pada waktu bersamaan sesuatu terjadi pada Y (cedera atau terluka)

$\mathrm{X}$ melakukan sesuatu dengan cara tertentu (tangan mengayun tangan dari bawah ke atas)

$\mathrm{X}$ melakukan sesuatu pada $\mathrm{Y}$ karena menginginkan $\mathrm{Z}$

$\mathrm{X}$ melakukan dengan benda tertentu (makhluk hidup:manusia dan hewan; benda mati, seperti batu, kayu, dll)

$\mathrm{X}$ melakukan tindakan dengan satu atau dua tangan

\section{SIMPULAN}

Berdasarkan analisis dan pembahasan di atas, dapat dipahami bahwa verba 'lempar' memiliki muatan dan bentuk yang berbeda-beda. Hal ini dapat diketahui melalui penggunaan teknik eksplikasi yang memerikan setiap entitas secara sederhana. Penggunaan kalimat bentuk kanonis (sederhana) ini bertujuan untuk mengidentifikasi makna asali yang termasuk dalam polisemi. Hasil yang diperoleh verba 'lempar' BSs memiliki fitur makna atau semantik yang kompleks dan berhasil dianalisis peneliti. Indikator ketuntasan analisis ini didapat atas postulat satu makna satu bentuk atau satu bentuk satu makna dalam leksikon yang tergabung dalam medan makna leksikon 'lempar'.

\section{DAFTAR PUSTAKA}

Allan, Keith. 2016. The Routledge Handbook of Linguistics. London: Routledge.

Goddard C. Cliff. 1997. Semantic Analysis: A Practical Introducing. Australia: The University of New England Armidale, NSW.

Mahsun. 2007. Edisi Revisi: Metode Penelitian Bahasa: Tahapan Strategi, Metode, dan Tekniknya. Jakarta: PT RajaGrafindo Persada. 
Recoeur, Paul. 2005. Filsafat Wacana: Membelah Makna dalam Anatomi Bahasa. Yogyakarta: IRCiSoD

Samarin, W. 1988. Ilmu Bahasa Lapangan. Seri ILDEP. Yogyakarta: Kanisius.

Sudariyanto. 1993. Metode dan Aneka Teknik Analisis Bahasa: Pengantar Penelitian Wahana Kebudayaan secara Linguistik. Yogyakarta: Duta Wacana University Press.

Sudipa, I Negah. 2004. Disertasi: Verba Bahasa Bali: Sebuah Analisis Metabahasa Semantik Alami. Denpasar: Universitas Udayana (tidak terbit).

Sutjiati-Beratha, NL.. 1997. "Basic Concept of Universal Semantics Metalanguage”. Jurnal Linguistika Tahun IV Edisi Keenam: 110-115.

Wierzbicka, Anna. 1996. Semantics: Primes and Universal. Oxford: Oxford University Press.

Wierzbicka, Anna. 2003. Cross-Cultural Pragmatics: The Semantics of Human Interaction. New York: Mouton de Gruyter. 